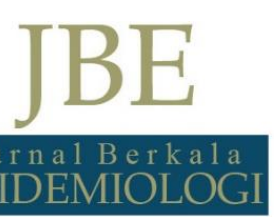

\title{
MEDIATION BY PSYCHOLOGICAL DISTRESS IN THE ASSOCIATION BETWEEN BULLYING VICTIMIZATION AND SUICIDAL BEHAVIORS AMONG ADOLESCENTS
}

\section{Mediasi oleh Distres Psikologis pada Hubungan antara Korban Bullying dan Perilaku Bunuh Diri pada Remaja}

I Gusti Ngurah Edi Putra ${ }^{1}$,, Ni Nyoman Astri Artini $^{2}$ (D)

${ }^{1}$ School of Health and Society, Faculty of the Arts, Social Sciences and Humanities, University of Wollongong, NSW, 2522, Australia, ediputra.ign@gmail.com

${ }^{2}$ Health Polytechnic Kartini Bali, Denpasar, 720471, Indonesia, astriartini@ gmail.com

Correspondence Author: I Gusti Ngurah Edi Putra, ediputra.ign@gmail.com, School of Health and Society, Faculty of the Arts, Social Sciences and Humanities, University of Wollongong, NSW, 2522, Australia

\section{ARTICLE INFO}

Article History:

Received August, $17^{\text {th }}, 2021$

Revised form August, 30 $0^{\text {th }}, 2021$

Accepted October, $8^{\text {th }}, 2021$

Published online January, $30^{\text {th }}, 2022$

\section{Keywords:}

bullying;

suicidal behaviors;

psychological distress;

adolescents;

causal mediation analysis

\section{Kata Kunci:}

bullying;

perilaku bunuh diri;

distres psikologis;

remaja;

analisis mediasi kausal

\begin{abstract}
Background: Bullying victimization has been found to be associated with suicidal behaviors among adolescents. However, there is a lack of studies examining the mediating pathways. Purpose: This study aims to investigate psychological distress as a candidate mediator to the association between bullying victimization and suicidal behaviors. Methods: This was a cross-sectional study involving 10,883 records of school-going adolescents, retrieved from the 2015 Indonesia Global School-based Student Health Survey (IGSHS). The primary independent variable was the experience of being bullied in the last 30 days. In contrast, the dependent variable was any suicidal behaviors (i.e., suicidal ideation, planning, or attempt) reported in the last 12 months. Psychological distress as a candidate mediator was measured as loneliness, anxiety-induced sleep disturbance (in the past 12 months), and a combination of both measures - psychological distress. Causal mediation analysis with single mediation models was used to investigate the mediation using psychological distress measures by adjusting for potential confounders. Results: This study found conceivable pathways linking bullying victimization to suicidal behaviors through all measures of psychological distress with statistically significant Natural Indirect Effect (NIE): loneliness $(\mathrm{aOR}=1.17 ; 95 \% \mathrm{CI}=1.11-1.27)$, anxiety-induced sleep disturbance $(\mathrm{aOR}=1.16 ; \quad 95 \% \mathrm{CI}=1.10-1.27), \quad$ and psychological distress $(\mathrm{aOR}=1.21 ; 95 \% \mathrm{CI}=1.15-1.31)$. The proportions mediated by loneliness, anxiety-induced sleep disturbance, and psychological distress accounted for $24.58 \%, 23.03 \%, 29.27 \%$, respectively. Findings also suggest that the mediation by all measures of
\end{abstract}


How to Cite: Putra, I. G. N. E., \& Artini, N. N. A. (2022). Mediation by psychological distress in the association between bullying victimization and suicidal behaviors among adolescents. Jurnal Berkala Epidemiologi, 10(1), 1-10. https://dx.doi.org/10.20473/jbe.v10i1 2022.1-10 psychological distress persisted among both genders, with higher proportions mediated reported among boys. Conclusion: Psychological distress mediated the associations between bullying victimization and suicidal behaviors among Indonesian adolescents.

C2022 Jurnal Berkala Epidemiologi. Published by Universitas Airlangga. This is an open access article under CC-BY-SA license

\section{ABSTRAK}

Latar Belakang: Korban bullying berkaitan dengan perilaku bunuh diri pada remaja. Akan tetapi, masih terdapat sedikit penelitian terkait faktor yang memediasi hubungan tersebut. Tujuan: Penelitian ini bertujuan untuk menyelidiki distres psikologis sebagai kandidat mediator dari hubungan antara korban bullying dengan perilaku bunuh diri. Metode: Penelitian ini menggunakan pendekatan cross-sectional study dengan melibatkan 10,883 remaja sekolah yang datanya diperoleh dari Indonesia Global School-based Student Health Survey tahun 2015. Variabel bebas utama yaitu pengalaman menjadi korban bullying dalam 30 hari terakhir, sedangkan variabel tergantung yaitu perilaku bunuh diri (ide atau pemikiran, perencanaan, dan percobaan bunuh diri) yang dilaporkan dalam 12 bulan terakhir. Distress psikologis sebagai kandidat mediator diukur sebagai perasaan kesepian, gangguan tidur yang dipicu kecemasan, dan kombinasi dari kedua pengukuran tersebut yang selanjutnya disebut distres psikologis. Analisis mediasi kausal dengan model mediasi tunggal digunakan untuk menyelidiki distres psikologis sebagai kandidat mediator dengan mengontrol pengaruh variabel perancu. Hasil: Penelitian ini menemukan beberapa jalur potensi yang mengubungkan korban bullying dengan perilaku bunuh diri melalui semua pengukuran distres psikologis dengan natural indirect effect (NIE) yang signifikan secara statistik: kesepian (aOR=1,17; 95\%CI=1,111,27), gangguan tidur yang dipicu oleh kecemasan (aOR=1,16; 95\%CI=1,10-1,27), dan kombinasi distres psikologis $(a O R=1,21 ; 95 \% C I=1,15-1,31)$. Proporsi mediasi oleh kesepian, gangguan tidur yang dipicu oleh kecemasan, dan distres psikologis yaitu masing-masing sebesar 24,58\%, 23,03\%, 29,27\%. Hasil penelitian ini juga memperoleh bahwa mediasi oleh seтиa pengukuran distres psikologis terjadi pada laki-laki dan perempuan dengan proporsi mediasi yang lebih besar pada laki-laki. Simpulan: Distres psikologis memediasi hubungan antara korban bullying dengan perilaku bunuh diri pada remaja Indonesia.

C2022 Jurnal Berkala Epidemiologi. Penerbit Universitas Airlangga. Jurnal ini dapat diakses secara terbuka dan memiliki lisensi CC-BY-SA

\section{INTRODUCTION}

Adolescence is a stage of human development that is vulnerable to mental health problems as they experience cognitive, physical, and social changes (Marsh, Chan, \& Macbeth, 2018). The World Health Organization (WHO) estimated that mental health problems account for $16 \%$ of the global burden of disease and injury among adolescents aged 10-19 years (World Health Organization, 2008). Globally, the prevalence of adolescent mental health problems ranges from 10$20 \%$ and around half of all mental health problems start before age 15 years, but most of the cases are undetectable (Kessler et al., 2007).

Suicide is estimated as the fourth leading cause of mortality among adolescents aged 15-19 years (World Health Organization, 2008). 
Adolescent suicide rates vary by country, ranging from 1.60 in the Bahamas to 24.30 per 100,000 in Lithuania among those aged 15-29 years (Cha et al., 2018). Suicidal behaviors are defined as a range of behaviors that cover suicidal ideation, planning, attempting, and completing suicide (Putra, Karin, \& Ariastuti, 2019). An analysis involving data from 82 countries showed that the pooled prevalence of suicidal ideation among adolescents is $14.00 \%$ (Biswas et al., 2020).

Bullying victimization among adolescents can be defined as any unpleasant experience of being exposed to adverse actions by peers, including verbal and physical bullying, and being socially ignored (Kusumawardani et al., 2015; Putra \& Dendup, 2020). A study using data from multiple countries found some correlates of bullying victimization, such as younger age, substance use, unfavorable mental health, and less peer support (Aboagye et al., 2021). No global figure is available to present the number of suicide deaths attributed to bullying victimization. Bullying victimization, however, was found to be associated with a range of adolescent mental health problems (e.g., anxiety, loneliness, depression, etc.), including suicidal behaviors (Moore et al., 2017; Pengpid \& Peltzer, 2019; Tang et al., 2020)

To date, it remains unclear regarding the pathway in which bullying victimization may influence suicidal behaviors among adolescents. Psychological distress - which is defined as symptoms of deeply unpleasant feelings or emotional suffering, such as anxiety, depressive symptoms, etc (McClelland, Evans, Nowland, Ferguson, \& O'Connor, 2020) - might mediate the association. Previous studies were examining factors associated with psychological distress among adolescents in Morocco and Liberia assessed psychological distress using a combined measure of loneliness and anxiety-induced sleep disturbance (Pengpid \& Peltzer, 2020, 2021). Past work found that bullying victimization is associated with psychological distress (Moore et al., 2017; Pengpid \& Peltzer, 2020, 2021) and psychological distress correlates with suicidal behaviors (Eskin et al., 2016). Based on these previous findings, psychological distress might lie in the association between bullying victimization and suicidal behaviors (Putra, Karin, \& Ariastuti, 2019). A lack of studies investigating mediation indicates that more studies are needed to address this research gap.

According to data from the Global Health Repository (GHO) in 2019, suicide rates among adolescents (10-19 years) and young adults (20-29 years) in Indonesia were 2 and 5.10 per 100,000 people, respectively (Ministry of Health RI, 2019). No national reports indicate the suicide rates due to bullying victimization among adolescents. Previous studies examined the association between bullying victimization and suicidal behaviors among Indonesian school-going adolescents (Putra \& Dendup, 2020; Putra, Karin, \& Ariastuti, 2019). Those studies, however, did not investigate the mechanism or mediator in which bullying victimization may influence suicidal behaviors. This study aimed to investigate the mediation by psychological distress in the association between bullying victimization and suicidal behaviors among Indonesian adolescents. This study also used causal mediation analysis which has been increasingly used in public health studies to test a mediator of the association.

\section{METHODS}

This study utilized data from the 2nd round of Indonesia Global School-based Student Health Survey (IGSHS) conducted in 2015. This survey was undertaken by the Ministry of Health of Indonesia in collaboration with the World Health Organisation (WHO) and the Center for Disease Control and Prevention (CDC). IGSHS primarily aimed to document school-going adolescents' risk and protective factors of health-related behaviors. Anonymous questionnaires were administered to students in 75 junior and senior high schools, predominantly in Sumatera and Java islands, and other islands in Indonesia. The 2015 IGSHS applied two-stage clustered probability sampling by selecting schools using probability proportional to size (PPS) sampling. Then, selecting classrooms used systematic sampling. The 2015 IGSHS has obtained ethics approval from the Ethics Commission of the Ministry of Health (LB.02.01/5.2/KE.158/2015). Further information on the 2015 IGSHS's content, methodology, dataset, and general findings was available online (Kusumawardani et al., 2015). This present study only analyzed adolescents' records with complete information on suicidal behaviors as the dependent variable ( $n=10,883$ out of 11,142 records available in the 2015 IGSHS).

The dependent variable of this study was suicidal behaviors, defined as whether adolescents had ever seriously considered attempting, made a plan, or attempted suicide in the last 12 months before the survey. The leading independent variable was the experience of being bullied in the 
previous 30 days. This study investigated psychological distress as potential mediating variables, measured as loneliness, anxiety-induced sleep disturbance (in the last 12 months), and a combination of both measures (i.e., psychological distress), following the definition provided in previous studies (Pengpid \& Peltzer, 2020, 2021). In addition, the influence of potential confounders, such as gender, age, the experience of hunger (as a proxy for socioeconomic status), parental and peer support, were controlled in the analysis (Putra \& Dendup, 2020). Table 1 provided the description of variables used in this study.

Descriptive statistics were used to present the sample characteristics. This study used a single causal mediation analysis by fitting each psychological distress measure in separate mediation models. Causal mediation analysis used the counterfactual framework to decompose the total effect of the exposure. This analysis pointed its impact on outcomes to pathways that do not involve the mediator - Natural Direct Effect (NDE) and the pathway through the mediator natural indirect effect (NIE) (Dendup, Feng, O'Shaughnessy, \& Astell-Burt, 2021). This mediation analysis helps address the limitations of the traditional approach. The estimation of the indirect effect by combining two standard regression coefficients in the conventional approach might lead to the incorrect statistical analysis and flawed conclusion (Liu, Ulbricht, Chrysanthopoulou, \& Lapane, 2016; Putra, AstellBurt, Cliff, Vella, \& Feng, 2021).

Table 1.

Description of variables from the 2015 IGSHS

\begin{tabular}{|c|c|c|c|}
\hline Variables & Questions from the 2015 IGSHS & Response options & $\begin{array}{l}\text { Coding } \\
\text { scheme }\end{array}$ \\
\hline \multicolumn{4}{|c|}{ Independent variable } \\
\hline Bullying & $\begin{array}{l}\text { "During the past } 30 \text { days, on how many days } \\
\text { were you bullied?" }\end{array}$ & $\begin{array}{l}" 1=0 \text { days to } 7=\text { all } 30 \\
\text { days" }\end{array}$ & $\begin{array}{l}" 1=0 \text { (no) and } \\
\geq 2=1 \text { (yes)" }\end{array}$ \\
\hline \multicolumn{4}{|c|}{ Candidate mediators } \\
\hline Loneliness & $\begin{array}{l}\text { "During the past } 12 \text { months, how often have } \\
\text { you felt lonely?" }\end{array}$ & $" 1=$ never to $5=$ always" & $\begin{array}{l}\text { "1-3=0 (no) } \\
\text { and } 4-5=1 \\
\text { (yes)" }\end{array}$ \\
\hline $\begin{array}{l}\text { Anxiety- } \\
\text { induced sleep } \\
\text { disturbance }\end{array}$ & $\begin{array}{l}\text { "During the past } 12 \text { months, how often have } \\
\text { you been so worried about something that } \\
\text { you could not sleep at night?" }\end{array}$ & $" 1=$ ne & $\begin{array}{l}\text { "1-3=0 (no) } \\
\text { and } 4-5=1 \\
\text { (yes)" }\end{array}$ \\
\hline $\begin{array}{l}\text { Psychological } \\
\text { distress }\end{array}$ & $\begin{array}{l}\text { Initial responses for loneliness and anxiety- } \\
\text { induced sleep disturbance were recoded } \\
\text { "never }=0 \text {, rarely/sometimes }=1 \text {, most of the } \\
\text { time }=2 \text {, and always }=3 \text { " and then summed up. }\end{array}$ & & $\begin{array}{l}" 0-2=0 \text { (no) } \\
\text { and } 3-6=1 \\
\text { (yes)" }\end{array}$ \\
\hline \multicolumn{4}{|c|}{ Dependent variable } \\
\hline $\begin{array}{l}\text { Suicidal } \\
\text { behaviors }\end{array}$ & $\begin{array}{l}\text { "Seriously considered attempting, made a } \\
\text { plan, or attempted suicide during the } 12 \\
\text { months before the survey." }\end{array}$ & $\begin{array}{l}\text { A "yes" response for } \\
\text { three suicidal behaviors } \\
\text { was scored } 1 \text { for each } \\
\text { and then added together. }\end{array}$ & $\begin{array}{l}" 0=0 \text { (no) and } \\
1-3=1 \text { (yes)" }\end{array}$ \\
\hline \multicolumn{4}{|c|}{ Potential confounders } \\
\hline Gender & "What is your sex?" & $" 1=$ male and $2=$ female" & $\begin{array}{l}" 2=0 \text { and } \\
1=1 "\end{array}$ \\
\hline Age & "How old are you?" & $\begin{array}{l}\text { "11 years old or younger } \\
\text { to } 18 \text { years old or older" }\end{array}$ & $\begin{array}{l}" \leq 15=0 \text { and } \\
>15=1 "\end{array}$ \\
\hline $\begin{array}{l}\text { Experience of } \\
\text { hunger }\end{array}$ & $\begin{array}{l}\text { "During the past } 30 \text { days, how often did you } \\
\text { go hungry because there was not enough food } \\
\text { in your home?" }\end{array}$ & $" 1=$ never to $5=$ always" & $\begin{array}{l}\text { "1-3=0 (no) } \\
\text { and } 4-5=1 \\
\text { (yes)" }\end{array}$ \\
\hline $\begin{array}{l}\text { Parental } \\
\text { support }\end{array}$ & $\begin{array}{l}\text { "During the past } 30 \text { days, how often did your } \\
\text { parents or guardians understand your } \\
\text { problems and worries?" }\end{array}$ & $" 1=$ never to $5=$ always" & $\begin{array}{l}\text { "1-3=0 (no) } \\
\text { and } 4-5=1 \\
\text { (yes)" }\end{array}$ \\
\hline Peer support & $\begin{array}{l}\text { "During the past } 30 \text { days, how often were } \\
\text { most of the students in your school kind and } \\
\text { helpful?" }\end{array}$ & $" 1=$ never to $5=$ =always" & $\begin{array}{l}\text { "1-3=0 (no) } \\
\text { and } 4-5=1 \\
\text { (yes)" }\end{array}$ \\
\hline
\end{tabular}


In addition, causal mediation analysis allows the presence of exposure-mediator interaction and can be used for mediation models with continuous and categorical variables (Valeri \& VanderWeele, 2013). This mediation method has been increasingly employed by studies in public health using longitudinal (Dendup, Feng, O'Shaughnessy, \& Astell-Burt, 2021; Putra, Astell-Burt, Cliff, Vella, \& Feng, 2021) and crosssectional study designs (Tarp et al., 2018).

For this study, bullying victimization as the exposure, psychological distress as the candidate mediator, and suicidal behaviors were fitted in separate single mediation models by controlling the influence of gender, age, the experience of hunger, and parental and peer support. This study followed published guidelines in conducting causal mediation analysis (Valente, Rijnhart, Smyth, Muniz, \& MacKinnon, 2020). Direct, indirect, and total effects were reported as adjusted odds ratio (OR) along with bias-corrected 95\% confidence intervals (CIs) from bootstrapping for 1000 iterations. Proportion mediated was also calculated using the following formula: NDE*(NIE-1)/(NDE*NIE-1) (Dendup et al., 2021).

\section{RESULTS}

Table 2 shows the characteristics of the samples. Almost balanced proportions between girls and boys ( $51.49 \%$ vs. $48.27 \%$ ) were reported in this study. The majority of adolescents are 15 years and under $(82.13 \%)$. Less than $5 \%$ of the adolescents notified that they often went hungry because of not enough food at home. Moreover, around one out of three adolescent students reported receiving adequate parental $(34.54 \%)$ and peer support $(39.10 \%)$. Comparing genders, girls were found to receive higher percentages of parental and peer support than boys.

The prevalence of bullying victimization in the last 30 days among Indonesian school-going adolescents was $18.61 \%$ with a higher prevalence reported among boys than girls $(21.08 \%$ vs. $16.27 \%$ ). For psychological distress measures, $5.73 \%$ and $4.30 \%$ of adolescents notified feeling lonely and anxious during the previous 12 months. The overall percentage of combined physical distress was $7.58 \%$. Loneliness and combined psychological distress were found to be more prevalent among female students, but male students were observed with a slightly higher prevalence of anxiety-induced sleep disturbance. Moreover, the pervasiveness of any suicidal behaviors was $8.82 \%$. The majority was found to be almost similar between females and males $(8.95 \%$ vs. $8.64 \%)$.

Table 3 presents the results from causal mediation analysis. Findings suggest that all measures of psychological distress (i.e., loneliness, anxiety-induced sleep disturbance, and combined psychological distress) partially mediated the association between bullying victimization and suicidal behaviors, irrespective of gender. For example, the indirect effect of bullying victimization on suicidal behaviors through loneliness presented as an adjusted odds ratio (AOR) was $1.17(95 \% \mathrm{CI}=1.11-1.27)$. This is interpreted as if all adolescents reported to be the party being bullied, the odds of suicidal behaviors would be $17 \%$ higher if they were lonely than those who were not. In addition, the odds of suicidal behaviors would be $16 \%$ (AOR=1.16; $95 \% \mathrm{CI}=1.10-1.27)$ and $21 \% \quad(\mathrm{AOR}=1.21$; $95 \% \mathrm{CI}=1.15-1.31$ ) higher if adolescents reported anxiety-induced sleep disturbance and combined psychological distress than those who did not, respectively. The interpretation of these findings was informed by published literature (Dendup et al., 2021). The proportions mediated through loneliness, anxiety-induced sleep disturbance, and combined psychological distress were $24.58 \%$, $23.03 \%$, and $29.27 \%$, respectively. Moreover, the proportions mediated by loneliness and combined psychological distress were found higher among boys than girls.

\section{DISCUSSION}

Overall, this current study found that all measures of psychological distress partially mediated the association between bullying victimization and suicidal behaviors after considering the influence of age, gender, experience of hunger, and parental and peer support. Combined psychological distress was found to be more mediated than loneliness and anxiety-induced sleep disturbance. In addition, the mediation by all measures of psychological distress persisted among both genders that also help strengthen the findings. Boys were reported with higher proportions mediated loneliness and psychological distress than girls. 
Table 2.

Characteristics of the samples

\begin{tabular}{|c|c|c|c|c|c|c|}
\hline \multirow{2}{*}{ Variables } & \multicolumn{2}{|c|}{ Females } & \multicolumn{2}{|c|}{ Males } & \multicolumn{2}{|c|}{ All samples } \\
\hline & $\mathrm{n}$ & $\% *$ & $\mathrm{n}$ & $\% *$ & $n$ & $\% *$ \\
\hline \multicolumn{7}{|l|}{ Age group } \\
\hline$\leq 15$ years & 4,789 & 82.08 & 4,030 & 82.34 & 8,831 & 82.13 \\
\hline$>15$ years & 1,148 & 17.91 & 889 & 17.66 & 2,038 & 17.76 \\
\hline Missing or not reported & 1 & 0.01 & & & 14 & 0.11 \\
\hline \multicolumn{7}{|l|}{ Experience of hunger } \\
\hline No & 5,695 & 96.11 & 4,659 & 94.94 & 10,380 & 95.55 \\
\hline Yes & 224 & 3.59 & 233 & 4.52 & 457 & 4.03 \\
\hline Missing or not reported & 19 & 0.30 & 27 & 0.54 & 46 & 0.41 \\
\hline \multicolumn{7}{|l|}{ Parental support } \\
\hline No & 3,677 & 61.48 & 3,293 & 67.28 & 6,984 & 64.28 \\
\hline Yes & 2,185 & 37.39 & 1,556 & 31.48 & 3,753 & 34.54 \\
\hline Missing or not reported & 76 & 1.12 & 70 & 1.24 & 146 & 1.18 \\
\hline \multicolumn{7}{|l|}{ Peer support } \\
\hline No & 3,323 & 55.08 & 3,176 & 64.78 & 6,514 & 59.77 \\
\hline Yes & 2,538 & 43.79 & 1,680 & 34.11 & 4,228 & 39.10 \\
\hline Missing or not reported & 77 & 1.13 & 63 & 1.12 & 141 & 1.13 \\
\hline \multicolumn{7}{|l|}{ Bullying victimization } \\
\hline No & 4,644 & 78.67 & 3,476 & 70.85 & 8,139 & 74.89 \\
\hline Yes & 975 & 16.27 & 1,043 & 21.08 & 2,024 & 18.61 \\
\hline Missing or not reported & 319 & 5.06 & 400 & 8.06 & 720 & 6.50 \\
\hline \multicolumn{7}{|l|}{ Loneliness } \\
\hline No & 5,505 & 93.02 & 4,641 & 94.29 & 10,170 & 93.63 \\
\hline Yes & 406 & 6.59 & 234 & 4.82 & 641 & 5.73 \\
\hline Missing or not reported & 27 & 0.38 & 44 & 0.89 & 72 & 0.64 \\
\hline \multicolumn{7}{|c|}{ Anxiety-induced sleep disturbance } \\
\hline No & 5,684 & 95.86 & 4,686 & 95.31 & 10,395 & 95.59 \\
\hline Yes & 249 & 4.08 & 223 & 4.52 & 473 & 4.30 \\
\hline Missing or not reported & 5 & 0.07 & 10 & 0.17 & 15 & 0.12 \\
\hline \multicolumn{7}{|l|}{ Psychological distress } \\
\hline No & 5,386 & 91.13 & 4,545 & 92.34 & 9,954 & 91.70 \\
\hline Yes & 521 & 8.43 & 323 & 6.65 & 846 & 7.58 \\
\hline Missing or not reported & 31 & 0.44 & 51 & 1.02 & 83 & 0.72 \\
\hline \multicolumn{7}{|l|}{ Suicidal behaviors } \\
\hline No & 5,376 & 91.05 & 4,494 & 91.36 & 9,891 & 91.18 \\
\hline Yes & 562 & 8.95 & 425 & 8.64 & 992 & 8.82 \\
\hline Total & 5,938 & 100.00 & 4,919 & 100.00 & 10,883 & 100.00 \\
\hline
\end{tabular}

*weighted percentages; 26 observations with missing values on gender

Mediation by psychological distress on the association between bullying victimization and suicidal behaviors could be explained by previous study findings on the association between bullying victimization and psychological distress, and between psychological distress and suicidal behaviors. Previous studies found that bullying is associated with psychological distress, including loneliness and anxiety-induced sleep disturbance (Moore et al., 2017; Pengpid \& Peltzer, 2019; Putra \& Dendup, 2020). Bullying victimization is a negative form of peer interactions and a stressful life event that can lead to psychological distress (Plexousakis, Kourkoutas, Giovazolias, Chatira, \& Nikolopoulos, 2019). Those who are bullied also tend to have low self-esteem and be more anxious about peer interactions (Tsaousis, 2016). Bullying victimization can negatively impact socioemotional functioning and adjustment that can lead to difficulties in making friends. This situation can further deliver low-quality interactions with peers and less social support, increasing the feeling of loneliness (Putra \& Dendup, 2020). 
Table 3.

Mediation by the measures of psychological distress in the association between bullying victimization and suicidal behaviors

\begin{tabular}{|c|c|c|c|}
\hline Candidate mediators & $\begin{array}{c}\text { All samples } \\
\text { AOR }(95 \% \text { CI })\end{array}$ & $\begin{array}{c}\text { Females } \\
\text { AOR }(95 \% \mathrm{CI})\end{array}$ & $\begin{array}{c}\text { Males } \\
\text { AOR }(95 \% \mathrm{CI})\end{array}$ \\
\hline \multicolumn{4}{|l|}{ Loneliness } \\
\hline Natural direct effect (NDE) & $2.09(1.76-2.45)$ & $2.05(1.73-2.41)$ & $1.86(1.47-2.36)$ \\
\hline Natural indirect effect (NIE) & $1.17(1.11-1.27)$ & $1.17(1.11-1.27)$ & $1.22(1.13-1.41)$ \\
\hline Total effect & $2.44(2.08-2.89)$ & $2.39(2.05-2.85)$ & $2.27(1.83-3.00)$ \\
\hline Proportion mediated (\%) & 24.58 & 24.92 & 32.24 \\
\hline \multicolumn{4}{|l|}{ Anxiety-induced sleep disturbance } \\
\hline Natural direct effect (NDE) & $2.15(1.83-2.51)$ & $2.10(1.81-2.45)$ & $1.94(1.55-2.48)$ \\
\hline Natural indirect effect (NIE) & $1.16(1.10-1.27)$ & $1.16(1.10-1.27)$ & $1.14(1.08-1.27)$ \\
\hline Total effect & $2.49(2.15-2.99)$ & $2.43(2.11-2.93)$ & $2.20(1.80-2.86)$ \\
\hline Proportion mediated (\%) & 23.03 & 23.40 & 22.42 \\
\hline \multicolumn{4}{|l|}{ Psychological distress } \\
\hline Natural direct effect (NDE) & $2.03(1.75-2.38)$ & $1.99(1.71-2.35)$ & $1.82(1.44-2.29)$ \\
\hline Natural indirect effect (NIE) & $1.21(1.15-1.31)$ & $1.21(1.15-1.32)$ & $1.21(1.14-1.41)$ \\
\hline Total effect & $2.46(2.11-2.88)$ & $2.41(2.09-2.90)$ & $2.21(1.77-2.81)$ \\
\hline Proportion mediated $(\%)$ & 29.27 & 29.68 & 31.79 \\
\hline
\end{tabular}

Psychological distress might be an intermediate outcome of bullying victimization, which can further trigger suicidal behaviors (Putra \& Dendup, 2020). Findings from past work suggest that loneliness and/or anxiety-induced sleep disturbance are associated with suicidal behaviors among adolescents in different study settings (McClelland et al., 2020; Putra, Karin, \& Ariastuti, 2019). Psychological distress, such as loneliness might negatively influence social lives among adolescents that play essential roles in the development of suicidal risk. Adolescents with loneliness are more likely to present low social skills in maintaining social relationships (Lodder, Goossens, Scholte, Engels, \& Verhagen, 2016). They are also more likely to suffer from other mental health problems and have increased feelings of discomfort and conflict (Loades et al., 2020). This psychological distress may increase the level of painful feelings, leading to suicidal behaviors (Putra \& Dendup, 2020; Putra, Karin, \& Ariastuti, 2019).

This study also highlighted that proportions mediated by loneliness and combined psychological distress was higher among boys. Even though the prevalence of self-reported loneliness and psychological distress was higher among girls (Table 2), the influence of loneliness and psychological distress on suicidal behaviors might be more significant among boys. These findings can be interpreted within the sociocultural contexts of Indonesia. In most Asian countries, including Indonesia, males are expected to be strong emotionally. This social expectation can make them less open up and less likely to share their feelings with friends and families. In addition, they are less frequent than females to seek help when experiencing psychological distress (McKenzie, Collings, Jenkin, \& River, 2018). Further investigation is needed to explore gender differences in the mediation by psychological distress on the association between bullying victimization and suicidal behaviors among adolescents.

Findings from this study suggest the importance of anti-bullying programs implemented in schools that should play roles in preventing bullying and mitigating the detrimental effects of bullying among adolescent victims. The implementation of anti-bullying programs is essential to avert bullying, its intermediate consequences (e.g., psychological distress), and the subsequent adverse outcomes (e.g., suicidal behaviors). A collaboration between teachers, parents, related stakeholders in the education, child protection, health sectors, and non-governmental organizations (NGOs) is needed to design and implement the programs in a targeted manner. 


\section{Research Limitations}

Findings from this study should be carefully interpreted because of its limitations. This study was cross-sectional in design which implies that the causal relationship can not be deduced. Findings might also be subjected to reverse causation due to the nature of cross-sectional data. In addition, samples were predominantly collected in Java and Sumatera islands, and hence, findings might not be widely generalized to all Indonesian school-going adolescents.

The different recall period between the measure of bullying victimization (in the last 30 days), psychological distress and suicidal behaviors (in last 12 months) might affect the findings to some extent. In addition, a long recall period of 12 months might also lead to recall bias. It is also important to note that the findings might be influenced by social desirability bias. Having suicidal behaviors might not be viewed as appropriate due to cultural and religious values in Indonesia (Putra, Karin, \& Ariastuti, 2019), which might lead suicidal behaviors to being underreported. However, the use of anonymous selfadministered questionnaires might help minimize this bias. Furthermore, only psychological distress was examined in this study, signalling more investigation on other potential pathways is warranted. Future studies need to take into account the limitations of this study.

\section{CONCLUSION}

Psychological distress partially mediated the associations between bullying victimization and suicidal behaviors. Anti-bullying programs implemented in school settings might help reduce bullying and the occurrence of psychological distress, which in turn prevent suicidal behaviors among adolescents. Future studies with rigorous methodology (e.g., longitudinal study), and testing other potential pathways are warranted.

\section{CONFLICT OF INTEREST}

The author declares that there is no conflict of interest.

\section{AUTHOR CONTRIBUTIONS}

IGNEP: conceptualization, methodology, formal analysis, writing-original draft preparation, writing-reviewing and editing; NNAA: writingoriginal draft preparation.

\section{ACKNOWLEDGMENTS}

The author would like to thank the Ministry of Health of Indonesia, the World Health Organization (WHO), and the Center for Disease Control and Prevention (CDC) for conducting the study and making the dataset publicly available.

\section{REFERENCES}

Aboagye, R. G., Seidu, A.-A., Arthur-Holmes, F., Frimpong, J. B., Hagan, J. E., Amu, H., \& Ahinkorah, B. O. (2021). Prevalence and factors associated with interpersonal violence among in-school adolescents in Ghana: analysis of the global school-based health survey data. Adolescents, 1(2), 186198.

https://doi.org/10.3390/adolescents1020015

Biswas, T., Scott, J. G., Munir, K., Renzaho, A. M. N., Rawal, L. B., Baxter, J., \& Mamun, A. A. (2020). Global variation in the prevalence of suicidal ideation, anxiety and their correlates among adolescents: a population based study of 82 countries. EClinicalMedicine, $\quad 24, \quad 1-9$. https://doi.org/10.1016/j.eclinm.2020.10039 5

Cha, C. B., Franz, P. J., Guzman, E. M., Glenn, C. R., Kleiman, E. M., \& Nock, M. K. (2018). Suicide among youth-epidemiology, (potential) etiology, and treatment. Journal of Child Psychology and Psychiatry, 59(4), 460-482. https://doi.org/10.1111/jcpp.12831

Dendup, T., Feng, X., O'Shaughnessy, P., \& Astell-Burt, T. (2021). Perceived built environment and type 2 diabetes incidence: exploring potential mediating pathways through physical and mental health, and behavioural factors in a longitudinal study. Diabetes Research and Clinical Practice, 176, $1-10$. https://doi.org/10.1016/j.diabres.2021.10884 1

Eskin, M., Sun, J.-M., Abuidhail, J., Yoshimasu, K., Kujan, O., Janghorbani, M., ... Voracek, M. (2016). Suicidal behavior and psychological distress in university students: a 12-nation study. Archives of Suicide Research, 20(3), 369-388. https://doi.org/10.1080/13811118.2015.1054 055

Kessler, R. C., Angermeyer, M., Anthony, J. C., De Graaf, R., Demyttenaere, K., Gasquet, I., 
... World Mental Health Survey Consortium. (2007). Lifetime prevalence and age-of-onset distributions of mental disorders in the World Health Organization's world mental health survey initiative. World Psychiatry, 6(3), 168-176.

Kusumawardani, N., Rachmalina, Wiryawan, Y., Anwar, A., Handayani, K., Mubasyiroh, R., ... Permana, M. (2015). Perilaku berisiko kesehatan pada pelajar SMP dan SMA di Indonesia. Jakarta: Badan Litbangkes Kementerian Kesehatan RI. Retrieved August, 11, 2021, from http://www.who.int/ncds/surveillance/gshs/ GSHS_2015_Indonesia_Report_Bahasa.pdf ?ua $=1$

Liu, S. H., Ulbricht, C. M., Chrysanthopoulou, S. A., \& Lapane, K. L. (2016). Implementation and reporting of causal mediation analysis in 2015: a systematic review in epidemiological studies. BMC Research Notes, $\quad 9(1), \quad 1-21$. https://doi.org/10.1186/s13104-016-2163-7

Loades, M. E., Chatburn, E., Higson-Sweeney, N., Reynolds, S., Shafran, R., Brigden, A., ... Crawley, E. (2020). Rapid systematic review: the impact of social isolation adolescents in the context of COVID-19. Journal of the American of Child \& Adolescent Psychiatry, 59(11), 1218-1239. https://doi.org/10.1016/j.jaac.2020.05.009

Lodder, G. M. A., Goossens, L., Scholte, R. H. J., Engels, R. C. M. E., \& Verhagen, M. (2016). Adolescent loneliness and social skills: agreement and discrepancies between self-, meta-, and peer-evaluations. Journal of Youth and Adolescence, 45(12), 2406-2416. https://doi.org/10.1007/s10964-016-0461-y

Marsh, I. C., Chan, S. W. Y., \& Macbeth, A. (2018). Self-compassion and psychological distress in adolescents - a meta-analysis. Mindfulness, 9, 1011-1027. https://doi.org/10.1007/s12671-017-0850-7

McClelland, H., Evans, J. J., Nowland, R., Ferguson, E., \& O'Connor, R. C. (2020). Loneliness as a predictor of suicidal ideation and behavior: a systematic review and metaanalysis of prospective studies. Journal of Affective Disorders, 274, 880-896. https://doi.org/10.1016/j.jad.2020.05.004

McKenzie, S. K., Collings, S., Jenkin, G., \& River, J. (2018). Masculinity, social connectedness, and mental health: men's diverse patterns of practice. American Journal of Men's Health,
12(5),

$1247-1261$

https://doi.org/10.1177/1557988318772732

Ministry of Health RI. (2019). Situation and prevention of suicide. Ministry of Health RI. Jakarta. Retrieved August, 12, 2021, from https://pusdatin.kemkes.go.id/resources/dow nload/pusdatin/infodatin/infodatin-Situasidan-Pencegahan-Bunuh-Diri.pdf

Moore, S. E., Norman, R. E., Suetani, S., Thomas, H. J., Sly, P. D., \& Scott, J. G. (2017). Consequences of bullying victimization in childhood and adolescence: a systematic review and meta-analysis. World Journal of Psychiatry, $\quad 7(1), \quad$ 60-76. https://doi.org/10.5498/wjp.v7.i1.60

Pengpid, S., \& Peltzer, K. (2019). Bullying victimization and externalizing and internalizing symptoms among in-school adolescents from five ASEAN countries. Children and Youth Services Review, 106, 17.

https://doi.org/10.1016/j.childyouth.2019.10 4473

Pengpid, S., \& Peltzer, K. (2020). Prevalence and associated factors of loneliness among a national sample of in-school adolescents in Morocco. Journal of Psychology in Africa, 31(3), 303-309. https://doi.org/10.1080/14330237.2021.1928 918

Pengpid, S., \& Peltzer, K. (2021). Prevalence and associated factors of psychological distress among a national sample of in-school adolescents in Liberia. Journal of Psychology in Africa, 31(2), 197-202. https://doi.org/10.1080/14330237.2021.1903 158

Plexousakis, S. S., Kourkoutas, E., Giovazolias, T., Chatira, K., \& Nikolopoulos, D. (2019). School bullying and post-traumatic stress disorder symptoms: The role of parental bonding. Frontiers in Public Health, 7, 115.

https://doi.org/10.3389/fpubh.2019.00075

Putra, G. N. E., \& Dendup, T. (2020). Health and behavioural outcomes of bullying victimisation among Indonesian adolescent students: findings from the 2015 global school-based student health survey. Psychology, Health \& Medicine, 1-15. https://doi.org/10.1080/13548506.2020.1826 546

Putra, I. G. N. E., Astell-Burt, T., Cliff, D. P., Vella, S. A., \& Feng, X. (2021). Do physical activity, social interaction, and mental health 
mediate the association between green space quality and child prosocial behavior? Urban Forestry \& Urban Greening, 64, 1-13. https://doi.org/10.1016/j.ufug.2021.127264

Putra, I. G. N. E., Karin, P. A. E. S., \& Ariastuti, N. L. P. (2019). Suicidal ideation and suicide attempt among Indonesian adolescent students. International Journal of Adolescent Medicine and Health, 33(5). https://doi.org/doi:10.1515/ijamh-2019-0035

Tang, J. J., Yu, Y., Wilcox, H. C., Kang, C., Wang, K., Wang, C., ... Chen, R. (2020). Global risks of suicidal behaviours and being bullied and their association in adolescents: School-based health survey in 83 countries. EClinicalMedicine, 19, 1-11. https://doi.org/10.1016/j.eclinm.2019.10025 3

Tarp, J., Bugge, A., Andersen, L. B., Sardinha, L. B., Ekelund, U., Brage, S., ... Collaborators, O. behalf of the I. C. A. D. (ICAD). (2018). Does adiposity mediate the relationship between physical activity and biological risk factors in youth?: a cross-sectional study from the international children's accelerometry database (ICAD). International Journal of Obesity, 42(4),
671-678.

https://doi.org/10.1038/ijo.2017.241

Tsaousis, I. (2016). The relationship of self-esteem to bullying perpetration and peer victimization among schoolchildren and adolescents: a meta-analytic review. Aggression and Violent Behavior, 31, 186199.

https://doi.org/10.1016/j.avb.2016.09.005

Valente, M. J., Rijnhart, J. J. M., Smyth, H. L., Muniz, F. B., \& MacKinnon, D. P. (2020). Causal mediation programs in $\mathrm{R}$, Mplus, SAS, SPSS, and Stata. Structural Equation Modeling: a Multidisciplinary Journal, 27(6), 975-984. https://doi.org/10.1080/10705511.2020.1777 133

Valeri, L., \& VanderWeele, T. J. (2013). Mediation analysis allowing for exposuremediator interactions and causal interpretation: theoretical assumptions and implementation with SAS and SPSS macros. Psychological Methods, 18(2), 137-150. https://doi.org/10.1037/a0031034

World Health Organization. (2008). Adolescent mental health. World Health Organization. Geneva.

https://doi.org/10.7748/ns.22.33.59.s47 